\title{
Prosecution of rape and sexual assault
}

The complexity involved in prosecuting sexual offences is reflected in the low numbers of successful convictions across jurisdictions. Research conducted in the last 20 years has highlighted that the majority of victims of sexual assault are female, most perpetrators are male, and a very small percentage of victims report this crime to the police. ${ }^{1}$ Media portrayals of 'real rape' present it as involving women being attacked outside their home, at night, by a stranger. This perception does not mirror reality. ${ }^{2}$ Women and girls are at most risk of physical or sexual violence from someone that they know and this familiarity can be problematic in the prosecution of sexual offences. The following paragraphs will outline the law relating to sexual offences in Scotland and England and Wales.

\section{Adults}

Sexual assault and rape

Since March 2002 the definition of the crime of rape in Scottish law now focuses on consent rather than 'overcoming the woman's will'. ${ }^{3}$ This reflects English law, however, male rape is not yet recognised in Scotland. Focusing on heterosexual rape, this requires that the accused ${ }^{4}$ had intercourse with a woman without her consent and that he either knew she was not consenting (i.e. he acted intentionally) or he was reckless as to whether or not she was consenting. In Scotland, sexual intercourse is strictly defined as vaginal penetration by the penis and ejaculation is not necessary. ${ }^{5}$ In England and Wales, sexual intercourse is defined as vaginal or anal penetration by the penis. ${ }^{6}$ Indecent assault ${ }^{7}$ is a form of aggravated assault and can be committed by a member of either sex against a member of either sex. If the parties agree to either sexual touching or intercourse no crime has been committed. Rape and sexual assault are therefore unusual in criminal law as the consent of the parties negates criminal responsibility. Only women over the age of 16 years can consent to sexual intercourse. There is no minimum age for the perpetrator of rape, however, he would have to at least be the age of criminal responsibility. ${ }^{8}$

In most rape and sexual assault trials, defence counsel do not suggest that the accused did not have intercourse or sexual relations with the woman but instead they suggest that these were consensual. Consequently at trial the onus is on the prosecution to prove that the complainer (the woman) did not consent to the actions of the accused and that the accused was aware that the woman did not consent or was reckless as to whether she was or was not consenting. 9 This results in a great deal of focus at trial being on the complainer and the rape trial being criticised as a second assault on the complainer. ${ }^{10}$ The focus on the complainer is exasperated in Scotland where an accused is not required to give evidence and no inference of guilt can be drawn from his silence. Proof of non-consensual intercourse is, therefore, very dependent on the complainer's evidence.

The difficulties in proving sexual assault and rape are further exasperated because of the context within which most crimes are alleged to be committed. The fact that the parties involved will usually know each other, that the complainer voluntarily went to the accused's home or invited him to her home and that a certain level of intimacy between the parties may have been consensual results in great difficulties for the prosecution in clearly defining that at a certain point consent was withheld and the accused was aware of this. Proof of this is not assisted by common sense perceptions that women will 'cry rape', for example, to preserve their reputation or take revenge if they are let down by a relationship.

The particular difficulties encountered in prosecuting rape and sexual assault mean that the complainer's evidence will not generally be adequate to lead to a conviction. In Scotland there requires to be corroborating evidence to add credibility to the complainer's position that there was no consent. This corroboration can be obtained from distress at first reporting the incident so long as it is in reasonable proximity to the crime and there is no other explanation for the distress. ${ }^{11}$ Anyone, including police and medical staff, could potentially be the person who is first told of the incident. Forensic evidence may also assist in establishing that intercourse or other sexual relations took place and whether this was consensual. Lack of consent can be corroborated by injuries. Evidence gained during a medical examination could therefore be critical in corroborating the woman's story. Although the formal requirement for corroborative evidence has been abolished in England and Wales ${ }^{12}$ there is no evidence that this has increased the possibility of conviction. In all cases, corroborating evidence, even if not strictly essential, will be of great assistance in any prosecution.

\section{Young complainers}

For young complainers, i.e. those under 16 years of age, there are specific provisions in both Scotland and England and Wales. Prosecutions involving young complainers face the same difficulties in proving charges as those involving adult complainers.

Rape

In respect of the crime of rape, Scotland has both common law and statutory provisions. Under the common law, intercourse with a girl under 12 years of age is rape whether or not this is consensual. Statutory provisions provide that it is an offence to have intercourse with a girl under 13 years, it is punishable by a maximum sentence of life imprisonment and the consent of the girl is no defence. ${ }^{13} \mathrm{It}$ is an offence to have intercourse with a girl between 13 and 16 years old. It is a defence if the man was under 24 years old, had no previous similar convictions and had reasonable cause to believe the girl was over 16 years old. ${ }^{14}$ In the prosecution of these offences corroboration will be required. Once again forensic evidence and distress evidence can be crucial to corroborating a complaint. It should be noted, however, that doubt over the credibility of distress is found in respect of both young and older complainers. In McLellan v H. M. Advocate, ${ }^{15}$ evidence of a child's distress when they first reported alleged lewd and libidinous behaviour was thought to be in part due to her fear of her mother reprimanding her for visiting the house where the alleged assault occurred. This first report of distress was, therefore, held not to corroborate the offence.

English law has similar provisions for the crime of rape, namely that intercourse with a girl under the age of 16 years 
is unlawful and if the girl is under 13 years it is punishable by life imprisonment. The girl can not consent to intercourse, however, if the man is under 24 years old, has not been previously charged with this offence or an attempt to commit this offence and he has reasonable cause to believe the girl is over 16 years old then he will not be guilty of an offence.

\section{Indecent assault}

In respect of indecent assault, boys and girls below the age of puberty ${ }^{16}$ are not deemed capable of consenting to acts which, without consent, would amount to indecent assault. This applies to heterosexual acts; for homosexual acts the age of consent is 16 years.

\section{Indecency involving children}

In Scots law it is a common law offence to behave in a lewd, indecent and libidinous manner towards children under the age of puberty. ${ }^{17}$ There is no defence of consent to this crime. If a boy or girl is over the age of puberty and they consent to heterosexual acts then there is no offence unless the actions fall within the offence of 'shameless indecency'. ${ }^{18}$ Under section 6 of the Criminal Law (Consolidation) (Scotland) Act 1995 it is a statutory offence to commit lewd practices towards a girl aged between 12 and 16 years. The girl's consent to such practices is irrelevant.

The relevant English law provisions prohibit acts of gross indecency ${ }^{19}$ with or towards children less than 16 years of age and make it an offence to incite a child to commit an act with him or another. ${ }^{20}$ This offence is necessary as an invitation to perform or participate in indecent acts is not an indecent assault under English law unless it is accompanied by force or threat of immediate force.

\section{Indecent exposure}

There is no separate crime of indecent exposure in Scots law. This act can be committed by a man or a woman and would be prosecuted as breach of the peace or a form of lewd practice. There is a statutory offence of indecent exposure in England and this prohibits a man exposing his penis in public or private with the intent to insult a female. ${ }^{21}$ The crime is, therefore, gender specific; however, indecent exposure by a man or a woman can constitute the common law offence of public nuisance or outraging public decency.

\section{Incest}

In Scotland incest is heterosexual intercourse between a child under the age of 16 years and his/her parent, sibling, grandparent, aunt/uncle, great grandparent, adoptive or former adoptive parent and by a person who is a member of the same household and is in a position of trust. The prohibitions also relate to relationships of half-blood. The crime of incest only relates to heterosexual intercourse and consequently homosexual acts and other forms of sexual misconduct are excluded. In English law incest relates to heterosexual intercourse between a man and his mother, daughter, sister or grand-daughter and between a woman and her grandfather, father, brother or son. ${ }^{22}$ Consent does not operate as a defence to a charge of incest and where consent is not present the crime of rape has been committed.

Statements on funding and competing interests

Funding. None declared.

Competing interests. None declared.

Clare Connelly, MA, LLB

Senior Lecturer in Law, School of Law, University of Glasgow, 8 Professor Square, Glasgow G12 8QQ, UK. Tel: +44 (0) 141330 4556. Fax: +44 (0) 141330 4900. E-mail: c.connelly@law.gla.ac.uk

Notes

See Hall R (1985) Ask any woman (Bristol: FallingWall Press); Chambers G, Millar A (1987) 'Proving sexual assault: prosecuting the offender or persecuting the victim' in Carlen P, Worrall A, Gender, crime and justice (Milton Keynes: Open University); Tempkin J (1987) Rape and the legal process (London: Sweet \& Maxwell); Brown B, Burman M, Jamieson L (1993) Sex crimes on trial (Edinburgh: Edinburgh University Press).

2 Hall R (1985) Ask any woman (Bristol: FallingWall Press). A total of 1236 women completed an extensive questionnaire on their experience of rape and sexual assault. More than one in six of the women had been raped (17\%), almost one in three had been sexually assaulted and one in five had survived attempted rape. Only $36 \%$ of women reported being raped by a stranger or strangers. One in five of the respondents reported having been raped or sexually assaulted as children or teenagers.

This change in definition was a result of a decision by the appeal court, Lord Advocate's Reference No. 1 of 2002 v Watt (22 March 2002), unreported at the time of writing. Most of the substantive criminal law in Scotland is common law and therefore changes in the law are the substantive criminal law in Scotlan
made by judges rather then Parliament.

made by judges rather then Parliam
'Defendant' in England and Wales.

Rape is a common law crime in Scotland. The definition can be found in Lord Advocate's Reference No. 1 of 2002 v Watt (22 March 2002), unreported at the time of writing.

6 Rape in England and Wales is a statutory offence contained within s.1 (1) of the Sexual Offences Act 1956 as substituted by the Criminal Justice and Public Order Act 1994, s. 142. Indecent assault is a form of aggravated assault. In Scotland this involves an intentional attack (interpreted very broadly and could involve touching) upon the person of another in circum and 15 of the Sexual Offences Act 1956. Any touching in circumstances of indecency or apprehension of being touched in such circumstances will be indecent assault.

This is 10 years in England and Wales and 8 years in Scotland, although the latter is under This is
review.

review.
In respect of rape if an accused honestly believes that the woman is consenting to intercourse he can not be guilty of rape. There needs to be an honest belief in consent but it is not required to be a reasonable belief. This departs from the usual standard adopted in Scottish criminal law where an objective test of reasonableness requires to be fulfilled. The relevant case in England and Wales is DPP v Morgan [1976] AC 182 and in Scotland Meek v H. M. Advocate 1983 S.L.T. 280.

10 Chambers G, Millar A (1987) 'Proving sexual assault: prosecuting the offender or persecuting the victim' in Carlen P, Worrall A, Gender, crime and justice (Milton Keynes: Open the victim' in Carlen P, Worall A, Gender, crime and justice (Milton Keynes: Open Brown B, Burman M, Jamieson L (1993) Sex crimes on trial (Edinburgh: Edinburgh University Press).

11 See, for example, Cannon v H. M. Advocate 1992 S.L.T. 709, where evidence of a complainer's distress exhibited some 12 hours after a rape was held to be corroborative when there was evidence that she had delayed disclosing her distress until she had the opportunity to speak to a close friend.

2 S. 32 (1) (b) Criminal Justice and Public Order Act 1994.

3 S. 5 Criminal Law (Consolidation) (Scotland) Act 1995.

4 S. 5 (5) Criminal Law (Consolidation) (Scotland) Act 1995.

1992 S.L.T. 991

6 Puberty is determined to be age 12 years for girls and 14 years for boys.

17 'Lewd indecent and libidinous practices and behaviour' may take the form of indecent handling of the child by the accused or inducing the child to indecently handle the accused. There is no need for actual contact between the parties and the offence would include indecent There is no need for actual contact be

18 'Shameless indecency' is a very broad crime and has been held to include indecent exposure, selling obscene literature and showing a pornographic film in private.

19 Gross indecency is deemed to be limited to activities involving the genitalia, including contact through clothing.

20 s. 1 (1) of the Indecency with Children Act 1960 as amended by s. 39 of the Criminal Justice and Court Services Act 2000

S. 4 of the Vagrancy Act 1824

22 The Scottish provisions were consolidated by the Incest and Related Offences (Scotland) Act 1986. The relevant provisions are now found in Criminal Law (Consolidation) (Scotland) Act 1995 (ss. 1-4). The English provisions are found in the 1956 Sexual Offences Act.

\section{Rape: The victim's perspective}

\section{What is rape?}

Rape laws originally came from the Roman law of 'raptus'. Raptus was a violent theft that could apply to any kind of property belonging to a man, including his wife or children. From the beginning, rape laws have been designed to protect a man's property, not to protect women. This is why, until 1992, a husband could not be prosecuted for raping his wife. A man could not be charged for taking what was legally his.

The modern definition of rape is that a man commits rape 